\title{
Confessionele hermeneutiek
}

\section{Vermittlungstheologie tussen belijden als opdracht en erfenis (1845-1855)}

\author{
J.C. Smits
}

\begin{abstract}
The reformed traditon features a tension between the historical confessions and the duty of confessing in response to God's revelation, which asks for a hermeneutics that understands the relation of contemporary Christians to ancient confessions. This article analyses the role of German theological movement of Vermittlungstheologie in this debate. After a sketch of the historical setting, the essay describes this movement's theories on the matter of a common protestant confession (among others, the dual principle), of the necessity of differentiation, and the resulting practical consequences for the church the last aspect on the basis of the Acts of the Generalsynode of 1846. The article concludes with a brief discussion of this movement's thought as a 'confessional hermeneutics'.
\end{abstract}

\section{Introductie}

De gereformeerde visie op belijden wordt gekenmerkt door ambivalentie. Waar de lutherse confessionele traditie tot een voltooiing kwam met de Concordia (1580), is er geen universeel gezaghebbende gereformeerde confessie. ${ }^{1}$ Belijdenissen hebben vaak een lokaal karakter (zoals de Nederlandse, Franse en Helvetische confessie(s)) of zijn met het oog op een specifiek doel opgesteld (zoals de Dordtse Leerregels). ${ }^{2}$ Dit gegeven leidt tot een corpus van in elk geval 127 gereformeerde confessies tussen 1523 en $1693 .{ }^{3}$ Een verkla-

1 Jan Rohls, Reformed Confessions: Theology from Zürich to Barmen, Westminster 1998, 9-10.

2 Vgl. Donald Sinnema, 'The Canons of Dordt: From Judgment on Arminianism to Confessional Standard', in: Aza Goudriaan, Fred van Lieburg (red.), Revisiting the Synod of Dordt (1618-1619), Leiden 2011, 335-366.

3 Zoals opgenomen in James T. Dennison jr., Reformed Confessions of the Sixteenth and Seventeenth Century in English Translation, (4 delen), Grand Rapids 2008-2014. Heiner Faulenbach, Eberhard Busch (red.), Reformierte Bekenntnisschriften (3 delen, 7 banden), Neukirchen-Vluyn 2002-2015 bevat 86 belijdenisgeschriften. 
ring voor deze pluriformiteit is dat belijden als activiteit in de gereformeerde traditie staat boven de tekstuele vastlegging van belijden. ${ }^{4}$ Vanuit dit principe vragen elke tijd en elke plaats om een nieuwe reactie op het goddelijk spreken van het Woord. ${ }^{5}$ Deze nadruk op voortdurend, telkens hernieuwd belijden sluit echter niet uit dat de oecumenische en reformatorische belijdenissen in de praktijk vaak een haast canonieke status genieten. In de Nederlandse context bijvoorbeeld, hebben Nederlandse Geloofsbelijdenis, Heidelbergse Catechismus en Dordtse Leerregels in veel geloofsgemeenschappen een belangrijke plek. Dit geldt ook in de Protestantse Kerk in Nederland, waar de recentere Barmer Thesen en de Leuenberger Konkordie weliswaar een confessionele status hebben, maar die status wel anders is dan die van de oecumenische geloofsbelijdenissen en belijdenisgeschriften van de Reformatie ('belijden in gemeenschap met' versus 'de betekenis van erkennen' of 'erkennen met'). ${ }^{6}$

Toch zijn ook in de breedte van de gereformeerde traditie de belijdenissen van de reformatie niet onproblematisch. ${ }^{7}$ De vraag dringt zich op hoe we om moeten gaan met belijdenissen die de sporen dragen van een theologische leefwereld en een visie op waarheid die niet langer de onze zijn. Voorbeelden van zulke sporen zijn de antipapistische polemiek van de Heidelbergse Catechismus, het theocratische ideaal van de Nederlandse Geloofsbelijdenis en de strenge antithese van de Dordtse Leerregels. Recente discussies laten een keur van strategieën zien om met deze kloof om te gaan, variërend van schrappen van 'achterhaalde' delen tot prioriteit geven aan de spiritualiteit van (of achter) een belijdenis ${ }^{8}$ tot het actualiseren van de toenmalige pole-

4 Michael Allen, 'Confessions', in: Paul T. Nimmo, David A.S. Ferguson (red.), The Cambridge Companion to Reformed Theology, Cambridge 2016, 28-30, 42; Eddy van der Borght, 'Reformed Ecclessiology', in: Gerard Mannion, Lewis S. Mudge (red.), The Routledge Companion to the Christian Church, New York/Abingdon 2007, 187-190.

5 Vgl. Gijsbert van den Brink, Johan Smits, 'The Reformed Stance: Distinctive Commitments and Concerns', in: Journal of Reformed Theology 9.4 (2015), 325-347.

6 Zie Kerkorde van de Protestantse Kerk in Nederland (versie juli 2019), artikel I, geraadpleegd op 23 oktober 2019. Beschikbaar via https://www.protestantsekerk.nl/download8316/ Kerkorde\%20en\%20ordinanties\%20-\%20versie\%20juli\%202019\%20definitief.pdf.

7 Bijvoorbeeld Hans-Georg Uhlrichs, 'Kritiek op de Heidelbergse Catechismus', in: Arnold Huijgen, John V. Fesko, Aleida Siller (red.), Handboek Heidelbergse Catechismus, Utrecht 2013, 156-157; 'Dordtse Leerregels krijgen in Nijkerk de handen niet op elkaar', reformatorisch Dagblad, 11-01-2018, 2-3.

8 Zie Arnold Huijgen, John V. Fesko, 'De relevantie van de Heidelbergse Catechismus', in: Huijgen, Fesko, Siller, Handboek Heidelbergse Catechismus, 383-392. 
miek. ${ }^{9}$ Kortom: in dit landschap lijkt bezinning op een confessionele hermeneutiek geen overbodige luxe.

Dit artikel stelt een belangrijke fase in de theologische reflectie op de confessie centraal, de midden-negentiende-eeuwse stroming van de Vermittlungstheologie. Deze beweging is allereerst geschikt om op deze vragen te reflecteren omdat er veel en diepgaand over de confessie werd nagedacht. Het eerste deel van dit artikel legt dan ook vanuit kerkpolitieke en theologische omstandigheden uit hoe deze beweging tot confessionele theologie veroordeeld raakte. Inhoudelijk is deze beweging interessant omdat zowel de historiciteit als de actualiteit van de gecodificeerde belijdenissen nadrukkelijk in beeld was. Het tweede deel beschrijft dan ook de theologische en hermeneutische overwegingen rond de confessie. Kenmerkende thema's zijn het dubbele principe van het protestantisme, de discussie over het onderscheidende aspect van lutheranisme en calvinisme en het debat over de Ordinationsverpflichtung. Ik besluit met een constructieve analyse, waarin ik een aantal richtingen wijs naar een 'confessionele hermeneutiek'.

\section{Op zoek naar confessionele identiteit}

De Reformatieherdenking van 1817 was voor de Pruisische Landeskirche om meer dan een reden memorabel, ${ }^{10}$ maar de kerkpolitieke gevolgen waren zonder twijfel het meest verstrekkend. Op 31 oktober 1817 vonden, als gevolg van een koninklijke Kabinettsordre gezamenlijke avondmaalsvieringen van gereformeerde en lutherse gemeenten plaats. ${ }^{11}$ Hiermee ontstond een avondmaalsgemeenschap van beide kerken in de Evangelische Kirche. Dit moment was echter geen eindstation, maar het startpunt voor feitelijke eenwording. Dit toch al precaire proces werd gecompliceerd door het gegeven dat de Union niet alleen een oecumenische gebeurtenis was, maar ook een centraliserende functie had. Gedurende de achttiende en negentiende eeuw vond in de Duitse staten een ontwikkeling naar een nationaal bewustzijn plaats. Dit werkte ook door in de provinciaal georganiseerde kerken, waar via een

9 Zie bv. J.M.D. de Heer, "Ik open mijn hart voor U': De actualiteit van het Dordtse debat rond algemene verzoening en vrije wil', in: W.J. op 't Hof e.a., Dordrechts erezuil: herdacht en herleefd, Apeldoorn 2018, 115-138.

10 Thomas Albert Howard, Remembering the reformation: An Inquiry into the Meanings of Protestantism, Oxford 2016, 35-65.

11 Klaus Wappler, 'Reformationsjubiläum und Kirchenunion (1817)', in: Johann F. Goeters, Joachim Rogge, Rudolf Mau (red.), Die Geschichte der Evangelischen Kirche der Union, Die Anfänge der Union unter landesherrlichem Kirchenregiment (1817-1850) (band 1), Leipzig $1992,112$. 
Pruisische Landeskirche een ontwikkeling plaatsvond naar een 'nationale' kerkelijke en academisch-theologische gemeenschap. Unionistische tendensen waren een onderdeel van deze centraliserende beweging en het debat over een protestantse unie werd dan ook breder dan alleen in Pruisen gevoerd. De ontwikkeling van Duitsland tot een eenheidsstaat in de negentiende eeuw was een belangrijke omgevingsfactor voor het debat over de identiteit van de Evangelische Kirche.

De beschreven ontwikkelingen impliceerden dat lutherse en gereformeerde kerken, die voorheen autonoom waren en provinciaal georganiseerd, op confessioneel en kerkordelijk niveau moesten samensmelten tot een kerk met een gezamenlijke identiteit en bestuur. Naast de kerkrechtelijke verschillen, bleek vooral de verhouding tot de confessie problematisch. Dit vraagstuk lag dicht bij het hart van de Union; de constituerende Kabinettsordre noemt als concrete aanleiding voor een Union dat de gezamenlijke geest van het protestantisme in beide kerken van de Reformatie aanwezig is. ${ }^{12}$ Door de Union worden slechts uiterlijke barrières tussen gereformeerde en lutherse kerken opgeheven. ${ }^{13}$ Naast het principiële aspect, dat in dit artikel centraal staat, had de confessionele vraag ook een kerkordelijke dimensie. De verschillende provinciale kerken bekenden zich tot verschillende belijdenisgeschriften en eisten van geestelijken een verschillende mate van binding aan de belijdenis. ${ }^{14}$

Hoewel de theologiegeschiedenis de periode van 1830-1870 vult met denkers als L.A. von Feuerbach en D.F. Strauss, die zich aan de randen van de (academische) theologie bewogen, was binnen de academische en kerkelijke theologie de gematigd liberale Vermittlungstheologie zeer prominent. Belangrijke vertegenwoordigers zijn Carl Immauel Nitzsch (Berlijn, 17871868), Carl Ullmann (Heidelberg, 1796-1865), Julius Müller (Halle, 18011878) en Isaak August Dorner (Berlijn, 1809-1884). Deze theologen waardeerden de eenwording positief en zagen het koninklijk besluit als een startsignaal voor een zoektocht naar de inhoud van de consensus van de lutherse en gereformeerde belijdenis. Dit standpunt met betrekking tot de Union had

12 Wappler, 'Reformationsjubiläum und Kirchenunion (1817)', 104-105.

13 Vgl. K.I. Nitzsch, 'Die Erklärung des Königs von Preußen Friedrich Wilhelm III. von 27 September 1817', in: idem, Urkundenbuch der Evangelischen Union mit Erläuterungen, Bonn 1853, 125-127.

14 Zie bv. I.A. Dorner, brief aan Martensen 27.06.1846, in: Anon., Briefwechsel zwischen H.L. Martensen und I.A. Dorner 1839-1881 herausgegeben aus deren Nachlass (band I), Berlijn $1888,179-180$. 
alles te maken met de missie van Vermittlung. ${ }^{15}$ Dit ideaal impliceerde in de eerste plaats een zoektocht naar een middenweg tussen de intellectuele extremen van rationalisme en supranaturalisme en daarmee naar een synthese van moderne theologie en orthodoxie. Dit was echter nauw verbonden aan het streven naar inhoudelijke verbinding van luthers en gereformeerd protestantisme. ${ }^{16}$ In dit artikel ligt de focus op de zoektocht naar confessionele Vermittlung.

Buiten de Vermittlungstheologie kon de Union niet op onverdeeld enthousiasme rekenen. De eerste groep die zich tegen de Union keerde, was die van de neoconfessionele lutheranen. ${ }^{17}$ De Berlijnse oudtestamenticus E.W. Hengstenberg (1802-1869) slaagde er met zijn Evangelische Kirchenzeitung in neoconfessionele lutheranen en piëtisten samen te smeden tot een belangrijke kerkpolitieke partij. ${ }^{18}$ Naast een conservatieve visie op het kerkbestuur, die een grote rol voor de vorst behelsde, stonden zij een nauwe binding van kerk en theologie aan de historische belijdenissen voor. Een van de belangrijke woordvoerders van deze beweging was de jurist Friedrich Julius Stahl (18021861). ${ }^{19}$ Hij definieerde het doel van zijn Die lutherische Kirche und die Union: Eine Wissenschaftliche Erörterung der Zeitfrage (1859) onder meer als 'het verdedigen van de lutherse kerk tegen de Union, het aantonen van de goddelijke waarheid van de lutherse belijdenis, het aantonen van de religieuze waarde van de [voor de lutherse kerk] onderscheidende leer, die geen gelijkstelling met een tegengestelde leer verdraagt'. ${ }^{20}$ Met die 'tegengestelde leer' zijn de gereformeerde theologie en belijdenis bedoeld; het grootste deel van Die

15 Zie voor een introductie Annette G. Aubert, The German Roots of Nineteenth-Century American Theology, Oxford 2013, 62-73, Ragnar Holte, Die Vermittlungstheologie: Ihre theologische Grundbegriffe kritisch untersucht, Uppsala 1965, 9 en Johan Smits, 'The Historical Mediation of God and Man: Vermittlungstheologie's Use of Hegelianism for Constructing a Theological System', in: Neue Zeitschrift für Systematische Theologie und Religionswissenschaft 60.1 (2018), 282-297.

16 Zie Joachim Mehlhausen, 'Rationalismus und Vermittlungstheologie. Unionstheologie und Hegelianismus an den preußischen Fakultäten', in: Goeters, Rogge, Geschichte der evangelische Kirche der Union (band 1) 175-210, 199.

17 Zie voor een algemene karakterisering Annette G. Aubert, 'Protestantism', in: Joel D. Rasmussen, Judith Wolfe, Johannes Zachhuber (red.), The Oxford Handbook of NineteenthCentury Christian Thought, Oxford 2017, 511-513.

18 Zie voor een overzicht Robert M. Bigler, The Politics of German Protestantism: The Rise of the Protestant Church Elite in Prussia, 1815-1848, Berkeley 1972, 53-158.

19 Bigler, The Politics of German Protestantism, 148.

20 Friedrich Julius Stahl, Die lutherische Kirche und die Union: Eine Wissenschaftliche Erörterung der Zeitfrage, Berlijn 1859, v. 
lutherische Kirche und die Union bestaat dan ook uit een analyse van de verschillen tussen beide reformaties. Een van de centrale inzichten uit Stahls onderzoek is dat de gereformeerde en lutherse confessie uit een verschillende motivatie stammen; waar voor Luther de zoektocht naar redding zijn diepste drijfveer was, werd het gereformeerd protestantisme gevormd door een ontkenning van het mysterie (Zwingli) en door een theocratisch (en dus aardsgericht) ideaal (Calvijn). ${ }^{21}$ Met het oog op deze verschillen, zo concludeert Stahl, kan het streven naar een kerkelijke vereniging dan ook slechts voortkomen uit een diepgewortelde onverschilligheid met betrekking tot het confessionele karakter van de lutherse kerk. ${ }^{22}$

Waar de neoconfessionele beweging een sterke nadruk legde op het inhoudelijke aspect van de belijdenissen, ontwikkelde zich aan de andere kant van het kerkelijke spectrum een beweging die sterk de nadruk legde op belijden als opdracht. ${ }^{23}$ De meest radicale vertegenwoordigers van deze denklijn kwamen aan de rand van de evangelische of lutherse kerk terecht en organiseerden zich als de Verein der Protestantischen Freunde. Deze beweging kenmerkte zich door afkeer van 'papieren confessies' en nadruk op het strikt persoonlijk karakter van het belijden. Zo benadrukte de oprichter van de Protestantische Freunde, Leberecht Uhlich (1799-1872), in zijn persoonlijke belijdenis de morele waarde van Jezus' leven, het Vaderschap van God en de transformerende kracht van de Geest en de hoop op Gods koninkrijk. ${ }^{24} \mathrm{Het}$ bestaan van deze liberale groepen stond vanaf het begin onder druk, omdat een stellingname ten gunste van leervrijheid en van een democratische kerkstructuur nauw verbonden was aan politieke idealen als vrijheid van meningsuiting en democratisering. ${ }^{25}$

21 Stahl, Die lutherische Kirche und die Union, 65.

22 Stahl, Die lutherische Kirche und die Union, 1-3, 80, 549-550.

23 Vroege voorbeelden hiervan zijn G.W.F. Hegel, 'Rede bei der dritten Säkularfeier der Übergabe der Augsburgischen Konfession (den 25. Juni 1830)', in: Gunter Jaeschke (red.), Philosophie und Literatur im Vormärz (Philosophisch-literarische Streitsachen 4.1 Quellenband), Hamburg 1999, 96-103; F.D.E. Schleiermacher, 'Predigten: Sechste Sammlung', in: F.D.E. Schleiermacher, Predigten: Fünfte bis Siebente Sammlung (18261833) Anhang: Gesangbuch zum gottesdienstlichen Gebrauch für evangelische Gemeinden (Berlin 1829) (KGA III.2), Berlijn 2015, 261-269.

24 [Leberecht Uhlich], Bekenntnisse von Uhlich: Mit Bezug auf die protestantische Freunde und auf erfahrene Angriffe, Leipzig 1845, 8-9.

25 Helmut Obst, 'Lichtfreunde, Deutschkatholiken und Katholisch-apostolische Gemeinden', in: Goeters, Rogge, Mau, Die Geschichte der Evangelischen Kirche der Union (band 1), 323324. 
Ook voor de lotgevallen van de gematigder Vermittlungstheologie bleek de relatie tussen politieke en theologische idealen beslissend. Dat pakte in de jaren na 1819, toen onder de Karlsbaddecreten het toezicht op de theologische faculteiten werd aangescherpt, relatief positief uit. ${ }^{26}$ Rationalistische theologen waren in deze periode verdacht door hun kritische houding ten opzichte van koninklijke invloed in de kerk. Dit bood mogelijkheden voor de Vermittlungstheologen, die over het algemeen als loyaler werden beschouwd. $\mathrm{Na}$ de dood van Friedrich Wilhelm III, die de Union had geïnitieerd, verslechterden onder Friedrich Wilhelm IV de omstandigheden ook voor de gematigde Vermittlungstheologie. In deze periode had de neoconfessionele stroming een stevige vinger in de pap aan het hof; vertegenwoordigers uit de kring van Hengstenberg, onder wie Stahl, waren belangrijke adviseurs van Friedrich Wilhelm IV. ${ }^{27}$ Hun visie op kerk en samenleving was van groot belang voor de restauratiepolitiek die Pruisen na de revoluties van 1848 zou inzetten. Kenmerkend voor de invloed van de neoconfessionelen zijn de koninklijke besluiten van 6 maart 1852 en 12 juli $1853 .{ }^{28}$ In het besluit van 1852 werd gesteld dat de Evangelische Kirche als een avondmaalsgemeenschap diende te worden geïnterpreteerd. Dit betekende dat het oorspronkelijke ideaal vanuit de gemeenschappelijke geest van beide confessies sterk werd afgezwakt. De gedachte hierachter was dat binnen de status-quo met lutherse en gereformeerde gemeenten, er door wederzijdse toegang tot de avondmaalstafels een feitelijke eenheid was. Deze federatieve benadering impliceerde dat er geen verdere stappen gezet hoefden te worden om die eenheid op kerkordelijk en confessioneel terrein te bewerkstelligen. Hoewel het besluit van 1853 het voortbestaan van de verenigde Evangelische Kirche garandeerde, betekende het in de praktijk dat de unie zich omvormde tot een paraplukerk die bestond uit gemeenten met een lutherse, gereformeerde of unionistische belijdenis.

\section{Op zoek naar relevante traditie}

De Pruisische kerk was ontstaan uit een veelvoud aan provinciale kerken, elk met hun eigen kerkrecht en praktijk op confessioneel gebied. Na de eenwording vormden de confessionele documenten van alle verenigende ker-

26 Bigler, The Politics of German Protestantism, 44, 159-162.

27 David L. Ellis, Politics and Piety: The Protestant Awakening in Prussia 1816-1856, Leiden/ Boston 2017, 193.

28 Zie Wilhelm H. Neuser, 'Union und Konfession', in: Joachim Rogge, Gerhard Ruhbach (red.), Die Geschichte der Evangelische Kirche der Union, Die Verselbständigung der Kirche unter dem königlichen Summepiskopat (1850-1918) (band 2), Leipzig 1994, 36-41. 
ken de confessionele basis van de nieuw ontstane kerk. Naast de drie oecumenische geloofsbelijdenissen ging het om de Augsburgse confessie, de Märkische, Franse en tweede Helvetische confessie, de beide catechismussen van Luther, de Heidelberger Catechismus, de Apologie van de Augsburgse Confessie, de Schmalkaldische artikelen, het Leipziger gesprek en de verklaring van Thorn.

Voor de zoektocht van Vermittlungstheologie naar consensus lijkt deze diversiteit aan documenten, praktijken en tradities weinig bevorderlijk. Toch waardeerden de aanhangers van deze stroming diversiteit positief ${ }^{29}$ en was deze diversiteit een integraal onderdeel van hun reflectie en kerkpolitiek handelen. De achtergrond van zowel reflectie als kerkpolitiek werd gekleurd door de idealistische wereldbeschouwing waarin de geschiedenis moet worden verstaan als de ontwikkeling van de geest, door middel van reflectie, naar zelfbewustzijn. Vanuit dit conceptuele kader ontwaarden de Vermittlungstheologen in historische gebeurtenissen een logica waarin concepten, waaronder ook leerstellingen, steeds verder werden uitgewerkt en begrepen. Hierin volgden drie fasen elkaar op. ${ }^{30}$ Uitgangspunt is (I) oorspronkelijke uniformiteit, waaruit zich (II) een tegenstelling vormt. Door de historische ontwikkeling ontstaat uiteindelijk (III) een synthese, waarin het oorspronkelijk begrip inhoudelijk is verdiept en rijker is geworden. Achtereenvolgens komen in deze paragraaf vanuit een theoretisch perspectief uniformiteit en ontwikkeling aan de orde, waarna het ontstaan van synthese vanuit praktisch oogpunt wordt belicht.

\subsection{Theorie I: uniformiteit}

Allereerst wees Vermittlungstheologie op een gemeenschappelijk uitgangspunt voor de tradities van luthers en gereformeerd belijden. Soms werd deze uniforme oorsprong verbonden aan een concreet historisch moment. Dit kon

29 I.A. Dorner, Sendschreiben über reform der evangelischen Landeskirchen im zusammenhang mit der Herstellung einer evangelisch-deutschen Nationalkirche; an Herrn D.C.J. Nitzsch in Berlijn und Herrn D. Julius Müller in Halle, Bonn 1848, 53; Carl Immanuel Nitzsch, Urkundenbuch der evangelische Union, x-xi; vgl. I.A. Dorner, Geschichte der protestantische Theologie, besonderes in Deutschland, nach ihrer principiellen Bewegung und in Zusammenhang mit dem religiösen, sittlichen und intellectuelen Leben betrachtet, München 1867, 775-776.

30 Carl Ullmann, 'Ueber Partei und Schule: Gegensätze und deren Vermittlung', in Carl Ullmann, Friedrich Wilhelm Carl Umbreit (red.), Theologische Studien und Kritiken: Eine Zeitschrift für das gesammte Gebiet der Theologie, in verbindung mit D. Gieseler, D. Lücke und D. Nitzsch dargestellt 9.1 (1836), 5-61. 
de vorm hebben van een bestaand belijdenisgeschrift, zo zag J. Müller de Augsburgse Confessie (1530) als basis van verdere confessionele ontwikkeling. ${ }^{31}$ De lutherse en gereformeerde traditie die zich hieruit ontwikkelden, zijn dus volgens hem in oorsprong al een; een positief startpunt voor de zoektocht naar consensus!

Andere aanhangers van het Vermittlungsproject wezen vooral op het bestaan van een inhoudelijke consensus, waarvan bijvoorbeeld Nitzsch en Müller een uitgewerkt voorstel gaven. ${ }^{32}$ De meeste weerklank vond echter de beschrijving van het protestantse belijden door middel van twee brandpunten, namelijk de Schrift en de rechtvaardiging uit het geloof als respectievelijk formeel en materieel principe van het protestantisme. ${ }^{33}$ Deze benadering van het eigene van de Reformatie is te herleiden op het werk van de Berlijnse dogmaticus W.M.L. de Wette (1780-1849). In zijn Lehrbuch der christlichen Dogmatik (1816) begon hij zijn bespreking van de protestantse dogmatiek met haar principes. Zijn omschrijving luidt:

Het principe van het protestantisme als verschijnsel (objectieve principe) is de leer van de vrije genade van God in Christus en van de rechtvaardiging door het geloof, of van verlossing en verzoening. De wijze van beschrijving en begrip is, zoals in het christendom als geheel, ethisch-dogmatisch, specifiek [voor het protestantisme] is echter de kritiek [in de zin van kritische methode, JCS] of het nastreven van terugkeer naar de oorspronkelijke openbaring. Het subjectieve, voortbrengende principe is zelfstandigheid (evangelische vrijheid), liefde tot de waarheid, levendigheid van het geweten, morele ernst. Aan de kant van het gevoel zijn devotie en overgave dominant. ${ }^{34}$

31 Julius Müller, Die evangelische Union, ihr Wesen und göttliches Recht, Berlijn 1854, 147.

32 Müller, Die evangelische Union, 170-205; Carl Immanuel Nitzsch, Urkundenbuch der evangelische Union, x-xi; vgl. ook I.A. Dorner, Geschichte der protestantische Theologie, vi-xi.

33 I.A. Dorner, Das Princip unsrer Kirche nach dem innern Verhältnis seiner zwey Seiten betrachtet: Eine dogmatische Abhandlung zur Feyer des 25jährigen Jubiläums des Amtsantrittes von D. Harms in Kiel, Kiel 1841; I.A. Dorner, 'Die deutsche Theologie und ihre Aufgaben in der Gegenwart', in: Jahrbücher für deutsche Theologie 1 (1856), 3-4; H. Martensen, Katholicismus und Protestantismus: Ein evangelisches Zeugni $\beta$, Gütersloh 1874, 108; August Neander, 'Das verflossene halbe Jahrhundert in seinen Verhältni $\beta$ zur Gegenwart', in: J.L. Jacobi (red.), Wissenschaftliche Abhandlungen von Dr. August Neander, Berlijn 1841, 234.

34 Wilhelm Martin Leberecht de Wette, Lehrbuch der christlichen Dogmatik in ihrer historischen Entwicklung, Die Dogmatik der protestantischen Kirche enthaltend (deel II), Berlijn 1840, 27. 
Het citaat maakt duidelijk dat voor De Wette de combinatie van het objectieve en subjectieve principe primair was. Opvallend is dat in De Wette's definitie de openbaringsleer secundair was ten opzichte van dit objectieve en subjectieve principe. Overigens gebruikte De Wette bij expliciete bespreking van de schriftleer wel de aanduiding unicum theologiae principium, ${ }^{35} \mathrm{zij}$ het dus pas in latere instantie. De stap van objectief/subjectief 36 naar materieel/formeel vond al snel plaats, namelijk in de Vorlesungen (1834) over De Wette's Lehrbuch door de (neoconfessionele) Berlijnse hoogleraar August Twesten (1789-1876). Hierin kregen De Wette's objectieve principe en zijn nadruk op Kritik prioriteit boven de andere aspecten van De Wette's formulering en werden zij aangeduid als respectievelijk materieel en formeel principe. ${ }^{37} \mathrm{De}$ gemoedsdimensie liet Twesten helemaal buiten beschouwing, de subjectieve dimensie herleidde hij tot het geloof en maakte hij secundair ten opzichte van de rechtvaardiging.

Deze combinatie van een materieel en formeel principe werd vrij algemeen binnen de kring van de Vermittlungstheologie. ${ }^{38}$ Dit concept diende drie functies. Allereerst gaven deze principes de mogelijkheid om het protestantisme als meest evenwichtige religie neer te zetten. Dorner beschreef bijvoorbeeld de principes van het protestantisme als ultieme combinatie van autoriteit (van het Woord) en vrijheid (van de gelovige). ${ }^{39}$ In de tweede plaats werden deze brandpunten ook aangewend als venster op de traditie van lutheranen en gereformeerden. Dorner en Martensen, bijvoorbeeld, benadrukken de rol van deze concepten in leven en theologie van Luther zelf. ${ }^{40}$ De laatste toepassing van de twee principes was polemisch van aard; waar ze de gereformeerde en lutherse traditie verbinden, sloten deze principes het katholicisme juist buiten. Een veelgebruikte redenering komt erop neer dat het

35 De Wette, Lehrbuch der christlichen Dogmatik (II), 28.

36 Overigens gebruikt De Wette bij bespreking van de Joodse godsdienst wel de terminologie formeel/materieel voor de relatie tussen objectief principe en wijze van beschrijving en begrip; zie Wilhelm Martin Leberecht de Wette, Lehrbuch der christlichen Dogmatik in ihrer historischen Entwicklung: Die biblische Dogmatik enthaltend (dl. I), Berlijn 1813, 59.

37 Aug. Detl. Chr. Twesten, Vorlesungen über die Dogmatik der Evangelisch-Lutherischen Kirche nach dem Compendium des Herrn Dr. W.M.L. de Wette (band I), Hamburg 1834, 274-281.

38 Verspreiding daarbuiten verliep in belangrijke mate via Philip Schaff, The Principle of Protestantism as related to the Present State of the Church (vert. John W. Nevin), Chambersburg 1845 en Richard Rothe, Zur Dogmatik, Gotha 1863, 19-26.

39 Dorner, 'Die deutsche Theologie und ihre Aufgaben in der Gegenwart', 12.

40 Dorner, Geschichte der protestantischen Theologie, 212-251; Martensen, Katholicismus und Protestantismus, 107-120. 
katholicisme eenzijdig de autoriteit van het subject benadrukt, doordat concilies en pauselijke uitspraken de noodzakelijke waarborg zijn voor de autoriteit van de Schrift. ${ }^{41}$ Dorner en Martensen stelden daarom dat scepticisme en rationalisme, die ook absolute zekerheid buiten het subject ontkennen, het onvermijdelijke gevolg van deze subjectivistische benadering zijn.

\subsection{Theorie II: conflict als ontwikkeling}

Deze positieve waardering van uniformiteit sluit niet uit dat het ontstaan van diversiteit als noodzakelijk werd gezien. Om dit te begrijpen is het begrip Vermittlung cruciaal. ${ }^{42}$ Kenmerkend is dat Vermittlungstheologie het hegeliaanse begrip Vermittlung niet alleen interpreteerde als een feitelijke beschrijving van het ontstaan van kennis, maar dit begrip ook een programmatische functie toekende. De belangrijkste verwoording hiervan is Karl Ullmann's essay Ueber Partei und Schule. Het ontstaan van groepen met tegengestelde standpunten in kerk en universiteit is volgens Ullmann noodzakelijk voor de ontwikkeling van kennis. ${ }^{43}$ Tegenstellingen zijn onmisbaar voor dieper inzicht. ${ }^{44}$ Hierin is de taak van de wetenschap om de kern van de tegenstelling aan het licht te brengen en om vervolgens de relativiteit van de tegenstelling ten opzichte van de eenheid aan te wijzen. ${ }^{45}$ Aan het eind ontstaat een samenhangend inzicht in de waarheid, waarin de oorspronkelijke these en antithese zijn gereduceerd tot momenten binnen de uiteindelijke synthese. Alleen op deze manier kan dieper begrip van het oorspronkelijke concept ontstaan. ${ }^{46}$

De toepassing van dit paradigma op de tegenstelling tussen de verschillende confessionele tradities was echter problematisch voor de Vermittlungstheologen. Vanuit bovenstaand denkkader volgt namelijk dat een thema voor Vermittlung op het terrein van de academie moest liggen en daarnaast een min of meer absolute tegenstelling moest vertonen. Met betrekking tot het eerste criterium was de confessie problematisch. Omdat confessies primair kerkelijk terrein zijn, waren de aanhangers van Vermittlungstheologie terug-

41 Zie vooral Martensen, Katholicismus und Protestantismus. Vgl. Dorner, 'Das Princip unsrer Kirche', 11-12; Dorner, 'The Infallibilism of the Vatican Council and Nominal Protestantism', in: Philip Schaff, Irenaeus Prime (red.), History, Essays, Orations, and Other Documents of the Sixth Conference of the Evangelical Alliance, Held in New York, October 2-12, 1873, New York 1874, 427-435.

42 Vgl. Smits, 'The Historical Mediation of God and Man', 282-297.

43 Ullmann, 'Ueber Partei und Schule', 22.

44 Ullmann, 'Ueber Partei und Schule', 18-19.

45 Ullmann, 'Ueber Partei und Schule', 48.

46 Ullmann, 'Ueber Partei und Schule', 41. 
houdend om deze academisch tegemoet te treden. ${ }^{47}$ Daarnaast was vanuit het criterium van de absolute contradictie het voorkeursonderwerp de tegenstelling tussen supranaturalisme, dat het bovenredelijke karakter van de openbaring vooropstelde, en rationalisme, dat de rede als kenbron juist een centrale plaats in de theologie gaf. ${ }^{48}$ Ullmann reduceerde bijvoorbeeld in Ueber Partei und Schule supranaturalisme en rationalisme tot schriftgeloof en wetenschap, die naar Ullmann's overtuiging verenigbaar zijn. ${ }^{49}$ In Das Wesen des Christenthums duidde hij leer en leven aan als kernpunten van respectievelijk het supranaturalisme en het rationalisme. ${ }^{50}$ Dorner verbindt het supranaturalisme aan het formele principe van het protestantisme en het rationalisme aan het materiële. ${ }^{51}$ Neander ten slotte noemde de tegenstelling protestantismekatholicisme als kandidaat voor een (toekomstige) Vermittlung. ${ }^{52}$

Het zal duidelijk zijn dat de lutherse en gereformeerde reformatie niet zo duidelijk tegenover elkaar stonden als deze stromingen. Toch vormde dit Vermittlungsparadigma in belangrijke mate het discours over confessionele ontwikkeling. Een voorbeeld is Julius Müller. Zijn visie op de confessies had als vooronderstelling dat de ontwikkeling van de leer zowel progressief als divergerend is. Hij keerde zich tegen het ontstaan van aparte kerken, maar benadrukte de legitimiteit van leerontwikkeling als Individualisering en Besonderung..$^{53}$ Concreet betekende dit dat hij, naast de Augsburgse Confessie als gemeenschappelijke basis, de andere belijdenissen als vastlegging van de historische ontwikkeling van de kerken wilde vasthouden. ${ }^{54}$ Op deze manier sloot zijn theorie van divergentie dus aan bij de idee van ontwikkeling van de confessie vanuit een uniforme bron.

Naast deze algemene erkenning van de legitimiteit van ontwikkeling binnen de protestantse traditie, pasten andere theologen het Vermittlungsparadigma meer expliciet toe op de confessie. Ullmann onderscheidt drie

47 Mülller, Die evangelische Union, 21.

48 Zie bv. Neander, Das verflossene halbe Jahrhundert', 215-268; Carl Ullmann, Das Wesen des Christenthums mit Beziehung auf neuere Auffassungsweisen desselben von Freunden und Gegern: Eine Erörterung auch für gebildete Nicht-Theologen, Hamburg 1849, 19-87; 'Ueber Partei und Schule', 37-40, 53-59. Zie ook I.A. Dorner, Geschichte der protestantische Theologie, 519-768, in het bijzonder 519-524.

49 Ullmann, 'Ueber Partei und Schule', 57.

50 Ullmann, Das Wesen des Christenthums, 19-43.

51 Dorner, Geschichte der protestantische Theologie, 523.

52 Vgl. Neander, 'Das verflossene halbe Jahrhundert', 254-256.

53 Müller, Die evangelische Union, 92-93.

54 Müller, Die evangelische Union, 148. 
typerende tegenstellingen in de christelijke theologie; in twee daarvan herkent hij de tegenstelling tussen de gereformeerde en lutherse reformatie. In de psychologische tegenstelling schrijft hij Luther een meer gelovig en Zwingli een meer verstandelijk perspectief toe, ${ }^{55}$ in de principiële tegenstelling ziet hij het lutheranisme als de voorloper van het supranaturalistische schriftgeloof, het calvinisme als de voorloper van het rationalisme. ${ }^{56}$ Neander ten slotte, beschreef de taak van theologie met betrekking tot de confessies in Vermittlungsidioom. ${ }^{57}$ Vanuit dat paradigma kon hij de Union waarderen als het opheffen van de uiterlijke grenzen tussen de confessies. De divergerende ontwikkeling van beide tradities was in het verleden noodzakelijk om een zo groot mogelijk bereik van het reformatorisch principe te faciliteren. Nadat lutheranen en gereformeerden echter weer één gemeenschap vormden, kon gezocht worden naar onderling begrip rond de verschillen en naar hogere eenheid in de principes. ${ }^{58}$

\subsection{Praktijk: kerk en gelovige}

Dit paradigma leidde ook naar de missie voor de kerk, Vermittlung was namelijk niet alleen reflectief naar het verleden, maar had ook als doel om de confessionele inhoud naar de moderne tijd te communiceren. ${ }^{59}$ Vermittlungstheologie legde daarbij niet zozeer de nadruk op de individuele gelovige, maar op het geheel van de kerk. ${ }^{60}$ Het moment waarop dit heel scherp naar voren kwam, was de Generalsynode van 1846. Deze vergadering is wel beschreven als het belangrijkste resultaat van Vermittlungstheologie. ${ }^{61}$ In een brief aan Martensen beschrijft Dorner de missie van deze, ten opzichte van supranaturalisme en rationalisme, nieuwe theologische stroming kernachtig:

Of het de vertegenwoordigers van de nieuwere theologie zal gelukken in deze onrust het verzoenende woord uit te spreken, dat moet op dit moment nog bezien worden. [Dat verzoenende woord kenmerkt zich] door het duidelijk

55 Ullmann, 'Ueber Partei und Schule', 34.

56 Ullmann, 'Ueber Partei und Schule', 36.

57 Neander, 'Das verflossene halbe Jahrhundert', 234-237.

58 Neander, 'Das verflossene halbe Jahrhundert', 235, 237.

59 Vgl. Dorner, Sendschreiben über reform, 79; Neander, 'Das verflossene halbe Jahrhundert', 234.

60 Bv. Dorner, Sendschreiben über reform, 51-59.

61 Heinrich Hermelink, Das Christentum in der Menschheitsgeschichte von der französische Revolution bis zur Gegenwart (band 2), Tübingen 1955, 338 (Geciteerd in Ellis, Politics and Piety, 137). 
uitspreken van het cruciale, principiële in zijn volheid, maar ook in zijn vermogen tot ontwikkeling, in zijn historische positie (in eenheid met de belijdenisgeschriften van de vaderen), maar ook in zijn voor de toekomst vrij baan makende en in zoverre nieuwe betekenis. Verder overhaast en dwingt [dit principiële] de Union niet, is het ook geen uiterlijk belemmerende, maar een innerlijk bevorderende kracht [voor de Union]. ${ }^{62}$

Friedrich Wilhelm IV, de koning van Pruisen, had met deze kerkvergadering een verdere uniformering van de Evangelische Kirche op het oog. ${ }^{63}$ Hoewel het uiteindelijke effect beperkt was, liep de synode uit op een diepgaande ontmoeting tussen de verschillende partijen binnen de Unionskirche. ${ }^{64}$ Belangrijke oorzaak hiervan was de samenstelling van de vertegenwoordigingen, die met name uit academici en hoge kerkelijke functionarissen bestonden.

Het belangrijkste discussiepunt op het gebied van de confessie vormde de zogenaamde Ordinationsverpflichtung. In dit schijnbaar ambtelijke punt kwam de discussie tussen Vermittlungstheologie, neoconfessionelen en rationalisten over de confessie op zijn duidelijkst naar voren. ${ }^{65}$ Feitelijk ging het bij de Ordination om de verplichting van afgestudeerde theologen om zich aan het geloof van de Landeskirche te conformeren, waardoor beroep naar een gemeente mogelijk werd. Bij de Vokation door de gemeente vond vervolgens binding aan de specifieke belijdenis van die gemeente plaats. ${ }^{66}$ In dit dossier had Vermittlungstheologie een grote stem; onder meer Nitzsch, Müller en Dorner waren betrokken bij de verschillende fases van het opstellen van een formule voor deze Ordination. ${ }^{67}$ Er waren drie aspecten van de Ordination die de Vermittlungstheologe aanspraken.

Allereerst zagen zij de Ordination als een geschikt moment om het gemeenschappelijke van de verenigde kerken te benadrukken, zonder dat dit zou lei-

62 I.A. Dorner, brief aan Martensen 27.06.1846, in: Briefwechsel I., 178. Cursiveringen Dorner.

63 Ellis, Politics and Piety, 131-134; Wilhelm H. Neuser, 'Landeskirchiliche reform-, Bekenntnisund Verfassungsfragen. Die Provinzialsynoden und die Berlijner Generalsynode von 1846', in: Goeters, Rogge, Mau, Die Geschichte der Evangelischen Kirche der Union (band 1), 343-345.

64 Vgl. Neuser, Landeskirchliche reform-, Bekenntnis- und Verfassungsfragen', 349, 365-366.

65 Vgl. Dorner, Sendschreiben über Reform, 38-39.

66 Vgl. 'Denkschrift, betreffend die Verpflichtung der Geistlichen auf die Bekenntnißschriften und die Verhandlungen der Provinzialsynoden über Reinheit und Einheit der Lehre', in: Anon., Verhandlungen der evangelischen General-Synode zu Berlin von 2. Juni bis zum 29. August 1846 (2. Abtheilung), Berlijn 1846, 45.

67 Neuser, 'Landeskirchliche reform-, Bekenntnis- und Verfassungsfragen', 350, 358. 
den tot het overhaast uitvlakken van de bestaande verschilpunten tussen de confessies. In zijn toelichting op het eerste voorstel gaf Nitzsch aan dat deze manier van doen past bij de polariteit van het kerkelijk leven; daarin is een bepaalde mate van verschil tussen de individuele gemeente en het gezamenlijk bewustzijn legitiem. ${ }^{68}$ Door bij de Ordination zich aan de protestantse traditie in het algemeen te verbinden en bij de Vokation aan de gemeente, zou dit in stand blijven. Dorner benadrukte daarnaast dat op deze manier het fundamentele van het niet-fundamentele wordt gescheiden. ${ }^{69}$ Door het gedeelde fundamentele te onderstrepen, zou de Ordinationsformel een belangrijk moment in de bewustwording van de uniforme identiteit moeten vormen.

Naast een formele bekrachtiging van het bestaande corpus aan belijdenissen, bevatte de formule ook een materiële vaststelling van de gemeenschappelijke leer van de reformatorische belijdenissen. ${ }^{70}$ Dit vormde de tweede reden voor het enthousiasme van de Vermittlungstheologe; een formule voor de Ordination bood de mogelijkheid om het wezenlijke van de protestantse traditie in een korte geloofsformule weer te geven. Belangrijkste punt was dat de 'typisch reformatorische' belijdenis van de band tussen Christus en de gelovige aan de orde diende te komen. Om deze reden kwam het Apostolicum dan ook niet in aanmerking als formule. ${ }^{71}$ Tegelijk maakte deze benadering van de formule de Vermittlungspartij kwetsbaar voor het belangrijkste bezwaar van zowel rationalistische als neoconfessionele zijde, namelijk dat de Ordinationsformel een verkapte nieuwe belijdenis vormde. Het leverde de Verpflichtungsformel de spotnamen Nitzschenum en Symbolum Berolinese op. ${ }^{72}$ Hoewel de vertegenwoordigers van Vermittlungstheologie zich hier krachtig tegen verzetten, ${ }^{73}$ hadden zij de schijn tegen.

Vermittlungstheologie zag, in de derde plaats, de Ordinationsformel ook als een middel om rationalisme en openbaringsgeloof terug te voeren naar de oorspronkelijke eenheid in de Schrift. Daarbij lag de nadruk op het 'gelovig' perspectief; de vertegenwoordigers van Vermittlungstheologie stonden over het algemeen een scheiding tussen academische theologie en kerkelijke praxis

68 Nitzsch op 18. Sitzung, in: Anon., Verhandlungen der evangelischen General-Synode, 137.

69 Dorner op 19. Sitzung, in: Anon., Verhandlungen der evangelischen General-Synode, 151.

70 Zo Nitzsch op 18. Sitzung, in: Anon., Verhandlungen der evangelischen General-Synode, 128; Müller op 20. Sitzung, in: Anon., Verhandlungen der evangelischen General-Synode, 167.

71 Sack op 20. Sitzung, in: in: Anon., Verhandlungen der evangelischen General-Synode, 172.

72 Neuser, 'Landeskirchliche reform-, Bekenntnis- und Verfassungsfragen', 354, 356.

73 Dorner op 19. Sitzung, in: Anon., Verhandlungen der evangelischen General-Synode, 151; Nitzsch op 21. Sitzung, in: Anon., Verhandlungen der evangelischen General-Synode, 183. 
voor. ${ }^{74}$ Om die reden kwam voor Müller de Augustana niet in aanmerking, omdat, naar zijn mening, hierin te vaak academische in plaats van kerkelijke discussies worden gevoerd. Om de gehele breedte van de kerk te kunnen bedienen, voldeden zelfs de drie oecumenische belijdenissen niet. Nitzsch gaf aan dat zij te veel zaken bevatten die niet rechtstreeks uit het evangelie afkomstig zijn of die resultaat zijn van latere leerontwikkeling. ${ }^{75}$ Het voorstel voor de Ordinationsformel was daarom gevat in woorden die ontleend waren aan de prediking van de apostelen. ${ }^{76}$ In de praktische uitwerking leidde dit ertoe dat leerstellingen die aanstootgevend waren voor de rationalisten, zoals de maagdelijke geboorte en de drie-eenheid, niet in het voorstel terechtkwamen. ${ }^{77}$ Vanuit het Vermittlungsbegrip van theologen als Nitzsch en Dorner impliceerde deze teruggang op het apostolisch getuigenis niet per definitie een terzijdestelling van de resultaten van latere leerontwikkeling. Tegelijk is de kritiek vanuit neoconfessionele hoek voorstelbaar. Juist deze kritiek zorgde ervoor dat, na ingrijpen van Friedrich Wilhelm, de Ordinationsformel nooit werd ingevoerd. ${ }^{78}$ Het is de tragiek van Vermittlungstheologie; de liefde van deze theologen voor het midden zorgde ervoor dat zij zich vervreemdden van de breedte en zo de confessionelen te modern en de modernen te behoudend waren. Dit zorgde ervoor dat hun standpunten in de kerk op langere termijn weinig effect hadden.

\section{Naschrift: hermeneutische evaluatie}

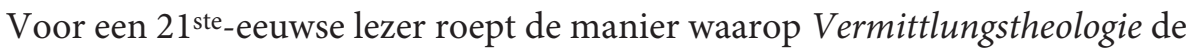
confessie benadert ongetwijfeld allerlei vragen op. Voor een deel is dit contextueel bepaald; de vragen die negentiende-eeuwers stelden aan de confessie waren anders dan de vragen die wij stellen. In deze evaluatie reflecteer ik op actualiteit en bruikbaarheid van dit denken voor een $21^{\text {ste-eeuwse }}$ confessionele hermeneutiek.

74 Johannes Wischmeyer, Theologiae Facultas: Rahmenbedingungen, Akteure und Wissenschafsorganisation protestantischer Universitätstheologie in Tübingen, Jena, Erlangen und Berlin 1850-1870, Berlijn/New York 2008, 285-287.

75 Nitzsch op 18. Sitzung, in: Anon., Verhandlungen der evangelischen General-Synode, 138; Müller in 20. Sitzung, in: Anon., Verhandlungen der evangelischen General-Synode, 176.

76 Nitzsch op 18. Sitzung, in: Anon., Verhandlungen der evangelischen General-Synode, 138.

77 Zie K.I. Nitzsch (red.), 'Gutachten der ersten Commission über die Verpflichtung der Geistlichen auf die Bekenntnißschriften', in: Anon., Verhandlungen der evangelischen General-Synode (2. Abth.), 79; Vgl. Neuser, 'Landeskirchliche reform-, Bekenntnis- und Verfassungsfragen', 356.

78 Neuser, 'Landeskirchliche reform-, Bekenntnis- und Verfassungsfragen', 364. 
1) De confessionele theologie van de Vermittlungstheologen confronteert ons in de eerste plaats met de complexe verhouding van protestanten tot belijden. Voor elke traditie met een vorm van confessie kan gezegd worden dat confessies een interpretatietraditie codificeren en een interpretatiegemeenschap afbakenen. ${ }^{79}$ Tegelijk is juist voor protestanten de confessie bij uitstek identiteitsvormend en -bepalend. Ik ga kort in op de consequenties voor de rol van de confessie ten opzichte van de Schrift en ten opzichte van de groep.

In de eerste plaats bestaat de identiteitsbepaling in een specifiek verstaan van de Bijbel. Dit levert spanning op: protestantisme staat enerzijds voor een telkens hernieuwd terug naar de Schrift, tegelijkertijd laat de confessie zien dat we de Schrift altijd lezen in een traditie van belijden. Het debat rond de Ordinationsformel laat zien hoe een confessionele traditie interpretatie zowel verdiept als beperkt. De tweede dimensie is die van de afbakening van een groep. In een confessie worden niet alleen interpretaties ingesloten, maar ook buitengesloten. Tegen die achtergrond is er spanning tussen een minimale en maximale opvatting van de confessie. Binnen het corpus van protestantse confessies is er enerzijds een katholieke breedte in de vorm van de oecumenische belijdenissen. Tegelijkertijd is er ook een nadere specialisering, die vaak haar context vindt in conflicten. Dit is vooral, maar niet uitsluitend, in de belijdenissen van de reformatie het geval. Het denken van Vermittlungstheologie probeert beide accenten in balans te brengen. Zo wordt er gezocht naar katholieke breedte, bijvoorbeeld wanneer de Ordinationsformel veel wegheeft van het Apostolicum. Tegelijkertijd keert het motief om het eigene van de protestantse traditie een plaats te geven telkens terug. De polen van Bijbel en belijdenis, katholiciteit en eigenheid vormen ook in de $21^{\mathrm{e}}$ eeuw uitdagingen voor een confessionele hermeneutiek.

2) Vermittlungstheologie benadert de vraag naar katholiciteit en eigenheid vanuit een historisch, en meer specifiek, hegeliaans denkkader. Belangrijke vooronderstelling is dat historische ontwikkeling van ideeën onmisbaar is om de waarheid te kennen. Het honoreren van historiciteit is correct en relevant, tegelijk is de vraag wat de concrete consequenties zijn in de reflectie van Vermittlungstheologie. Voor deze theologen is namelijk de fase van synthese bereikt, wat mogelijkheden biedt om de antithetische aspecten wel serieus te nemen, maar toch vooral vanuit een genealogische interesse. In de praktijk wordt de eigen positie sterk herleid op de oorspronkelijke uniformiteit, in dit

79 Vgl. Murray A. Rae, 'Creation and Promise: Towards a Theology of History', in: Craig Bartholomew, C. Stephen Evans, Mary Healy, Murray Rae (red.), 'Behind' the Text: History and Biblical Interpretation (Scripture and Hermeneutics Series 4), Grand Rapids 2003, 295-297. 
geval van de vroege kerk en van de reformatoren, met name Luther. Ook nu komt deze leesstrategie voor; we plaatsen onszelf in een katholieke lijn, waarbij we polemiek en andere tijdbetrokken aspecten liefst zo veel mogelijk buiten beschouwing laten. De vraag is of deze benadering van de confessie zoveel oplevert. Niet alleen is twijfelachtig of we de theoloog of confessie die we als 'totus noster' claimen wel recht doen. Het zou ook weleens kunnen zijn dat we meer hebben aan begrip van hoe onze traditie werkt, dan aan een selectie van teksten die ons gelijk ondersteunen. Dat wil niet zeggen dat de tijdbetrokken kant van de confessionele traditie niet anders gehonoreerd kan worden dan door de oude posities telkens te hernemen. In een poging om ook de tijdbetrokken elementen recht te doen, zou ik willen pleiten voor een minder essentialistische en meer dynamische opvatting van een confessionele traditie. In een eerdere publicatie pleitten G. van den Brink en ondergetekende voor een benadering van de gereformeerde traditie als een 'stance'. ${ }^{80} \mathrm{Het}$ begrip 'stance' duidt een filosofische of theologische positie als een cluster van attitudes, waarin zich naast propositionele overtuigingen, ook andere vormen van commitment, zoals theologische belangen, intuïties en waarden bevinden. In geval van protestantse tradities valt er niet aan te ontkomen om zo'n zienswijze in de eerste plaats te duiden als een leeswijze. Vanuit dit model laten confessies zich benaderen als codificaties van de belangrijkste kenmerken van de manier waarop een specifieke traditie de Schrift leest. Deze benadering past bij het afgeleide karakter van de autoriteit van belijdenisgeschriften: waarheid staat in het Woord, confessies leggen grondlijnen vast die de geloofsgemeenschap uit en in dat Woord heeft leren lezen. Kortom: in de confessie vinden we misschien wel niet in de eerste plaats 'hoe het zit', maar leren we 'hoe het moet'.

3) Vanuit deze dynamische traditie-opvatting zijn voorstellen voor een 'protestantse' confessie, zoals de Ordinationsformel en gedetailleerde concretiseringen als van Nitzsch en Müller, al te optimistisch en al te essentialistisch. Hoewel ook het denken in principes uit een romantisch/idealistisch denkkader voortkomt, zou ik willen betogen dat deze benadering van de protestantse confessie ook voor nu mogelijkheden biedt. Aan het werk van De Wette ontleent deze denkwijze namelijk een meer fenomenologische insteek. Hoewel De Wette's eigen uitwerking van de principes een sterk door de Romantiek gestempeld perspectief op het protestantisme biedt, doet de latere versie met twee principes meer recht aan de accenten van de confessie zelf. Het formele principe, in de eerste plaats, laat zien hoe onmisbaar de relatie tot het Woord 
is om protestantse confessie te begrijpen (zie boven bij 1 en 2). Hoewel de keuze voor de rechtvaardiging als materieel principe gekleurd is door de lutherse achtergrond van Vermittlungstheologie, sluit dit principe de gereformeerde traditie zeker niet uit. ${ }^{81}$ Dit principe geeft uitdrukking aan de basisintuïtie dat de verhouding tussen God en mens alleen door goddelijk ingrijpen kan worden rechtgezet. Protestant zijn is dus zich afhankelijk weten van goddelijk spreken - in de theologische reflectie - en van goddelijk vrijspreken in de persoonlijke verhouding tot God. Tegelijk geven deze principes ook aanleiding tot voortdurende (zelf)kritiek - van menselijk spreken en vrijspreken. Zo gelezen daagt de belijdenis uit om telkens opnieuw te lezen en vanuit die nieuwe lezing te spreken - mee te spreken, met het Woord en met gelovigen van alle tijden en plaatsen.

J.C. Smits is docent godsdienst en doet promotieonderzoek naar de relatie tussen theologie en nationalisme in Duitsland in de periode 1820-1870.

81 Vgl. Bruce Lindley McCormack, 'Protestant Identity as a Theological Problem', in: Volker Küster (red.), Reshaping Protestantism in a Global Context (Contactzone: Explorations in Intercultural Theology 1), Berlijn 2009, 177-194. 